\title{
FACTORS AFFECTING THE PERFORMANCE OF AN INDENTED CYLINDER SEPARATOR
}

\author{
Tawfik ,M.A. $^{1} \quad$ A.M. EI Shal $^{1} \quad$ Y.A. El Fawal ${ }^{2}$
}

\begin{abstract}
The aim of this study was to evaluate some engineering and operational factors affecting the performance of an indented cylinder separator on the basis of grain length for local varieties of two main grain crops in Egypt, wheat (Gimeza 7) and corn (hybrid-310).The evaluation was identified at various cylinder speeds of 30, 35, 40 and $45 \mathrm{rpm}$. corresponding to peripheral speeds of $0.94,1.10,1.26$ and $1.41 \mathrm{~m} / \mathrm{s}$ respectively, receiving trough angles of $30^{\circ}, 40^{\circ}, 45^{\circ}$ and $50^{\circ}$ and feed rate of $6,12,18$, and $24 \mathrm{~kg} / \mathrm{h}$ at cylinder slope of zero. The obtained results revealed that the separating efficiency decreased by increasing each of the cylinder speed, receiving trough angle and feed rate. Also, the results indicated that the cylinder separator can be operated at rotational speeds ranged from $30 \mathrm{rpm}(0.94 \mathrm{~m} / \mathrm{s})$ to $35 \mathrm{rpm}(1.10 \mathrm{~m} / \mathrm{s})$ and receiving trough angles from $30^{\circ}$ to $40^{\circ}$ and feed rate of $6 \mathrm{~kg} / \mathrm{h}$ to achieve the best values of separating efficiency with minimum percentage of lifted long grains in the trough for wheat and corn. So the combination of $30 \mathrm{rpm}(0.47 \mathrm{~m} / \mathrm{s})$ cylinder speed, $30^{\circ}$ trough angle, and $6 \mathrm{~kg} / \mathrm{h}$ feed rate is recommended for the highest values of separating efficiency of 92.54 and $91.35 \%$ for wheat and corn respectively.
\end{abstract}

Keywords: indented cylinder, peripheral speed, cylinder slope, trough.

\section{INTRODUCTION}

$\mathrm{I}$ n order to facilitate dealing with the post-harvest grain it must be separated from the large or small broken or incomplete maturation. The grain cleaning, reduces the problems that occur during storage, handling and manufacturing operations. The length separating is necessary to obtain equally long kernels therefore, length separating or grading of the agricultural grains may be required for precise planting or to satisfy marketing, food quality and food industry requirement.

\footnotetext{
${ }^{1}$ Lecturer, Agric. Eng. Dept. Fac. of Agric., Zagazig Univ., Egypt.

${ }^{2}$ Researcher, Agric. Eng. Res. Inst. (AEnRI) ,Cairo, Egypt
} 
Wang et al.(1994) mentioned that Impurities and contaminants found in grains including light material, foreign material, broken kernel, shrunken kernel, splits and fine or powdered material must be separated from grains during cleaning process. Fouad (1980) indicated that the results apply to a slowly revolving cylinder where the centrifugal force has a negligible effect on the fall of the kernels from the cell. Further investigation was to study the effect of the cylinder speed on the effectiveness of length separation of the new cell. Berlage $\boldsymbol{e t}$ al.(1984) used round holes perforated metal, in this model, the entire cylinder was wrapped with sheet metal. Although the machine made effective separation involving small length differences seeds tended to lodge in the square shouldered indent. They added that contaminants removal was related directly to cylinder slope and inversely to cylinder speed and feed rate, while crop loss was related inversely to cylinder speed and feed rate with a little effect by cylinder slope. Yamashita (1985) reported that in order to increase the separating accuracy using the indented cylinder separator, the following factors should be taken into consideration of cylinder angle, rate of feed, size of indent and separating time. Sarker (1993) indicate that performing precise removing of all foreign materials, that comes along with grains such as, wheat, barley and oats on the basis of length can be achieved by choosing the appropriate pocket size ,pocket shape and width of the indented cylinder. Hence, the main objective of this study was to optimize some operating parameters affecting the performance of a laboratory indented cylinder separator such as, cylinder rotational speed, trough angle, and feed rate using grains of two popular feed crops in Egypt named wheat and corn.

\section{MATERIALS AND METHODS}

The present study was carried out at the Agric. Eng. Res. Inst. (AEnRI ), Agricultural Research Station in Gemiza, El-Gharbia Governorate, Egypt. The laboratory experiments were performed using local varieties of two main field crops namely, wheat (Gemiza 7) and corn (hybrid 310) .Their selection based on their recent coverage area. The grains samples were cleaned manually to remove the foreign matters and impurities. Their properties were shown in Table (1). 
Table (1):Some physical and mechanical properties of the grain

\begin{tabular}{|c|c|c|c|c|c|c|c|c|c|}
\hline \multirow{2}{*}{ crop } & \multirow{2}{*}{$\begin{array}{c}\text { Bulk } \\
\text { density } \\
\left(\mathbf{k g} / \mathbf{m}^{3}\right)\end{array}$} & $\begin{array}{c}\text { Mean } \\
(\mathbf{m m})\end{array}$ & $\begin{array}{c}\text { C.V } \\
(\%)\end{array}$ & $\begin{array}{c}\text { Mean } \\
(\mathbf{m m})\end{array}$ & $\begin{array}{c}\text { C.V } \\
(\%)\end{array}$ & $\begin{array}{c}\text { Mean } \\
(\mathbf{m m})\end{array}$ & $\begin{array}{c}\text { C.V } \\
(\%)\end{array}$ & $\begin{array}{c}\text { Angle of } \\
\text { repose } \\
(\mathbf{d e g r e e})\end{array}$ & $\begin{array}{c}\text { Co. of } \\
\text { friction } \\
(\text { steel })\end{array}$ \\
\hline $\begin{array}{c}\text { Wheat } \\
\text { (Gimeza 7) }\end{array}$ & 730 & 6.75 & 5.92 & 4.10 & 14.87 & 3.45 & 14.20 & 27.40 & 0.32 \\
\hline $\begin{array}{c}\text { Corn } \\
\text { (hyb-310) }\end{array}$ & 830 & 12.30 & 8.51 & 8.24 & 15.10 & 4.53 & 19.93 & 20.60 & 0.41 \\
\hline
\end{tabular}

\section{The experimental indented cylinder separator}

The cylinder separator is an experimental apparatus which correspond to the indented cylinder in the grain cleaning and grading units either in mills or grinders. It consists of two basic parts, the indented cylinder and the receiving trough. Other parts, which are related to the effectiveness of the separation, receiving trough adjustment lever and electric motor, were illustrated in Fig.(1).

\section{The cylinder:}

It is a drum with both ends removed, and revolves around a horizontal central shaft and its dimensions are $300 \mathrm{~mm}$ in diameter and $600 \mathrm{~mm}$ in length. Cylinder walls are stamped steel lined with pockets formed into a shape a conical (tapered) with $6 \mathrm{~mm}$ in diameter for wheat and $8 \mathrm{~mm}$ in diameter for corn. For various cylinder speeds the machine was equipped by a variable speed drive motor. To increase or decrease, cylinder speed, the micro crank attachment with drive motor was turn clockwise or counter clockwise as shown in table(2). Motor shaft speed ranged from 30 rpm to $50 \mathrm{rpm}$ and transmitted to the rotating cylinder by gears and sprockets.

\section{The receiving trough:}

The adjustable receiving trough a device to receive the desired lifting's as shown in Fig.(2). The degree of separation is controlled by the position of the separating edge of the receiving trough adjacent to rising side of the cylinder. The angle of the separating edge of the receiving trough ranged from $10^{\circ}$ to $50^{\circ}$. The test apparatus under study have available position device. It can be adjusted by changing the position of setting device lever on the scale of the machine. 

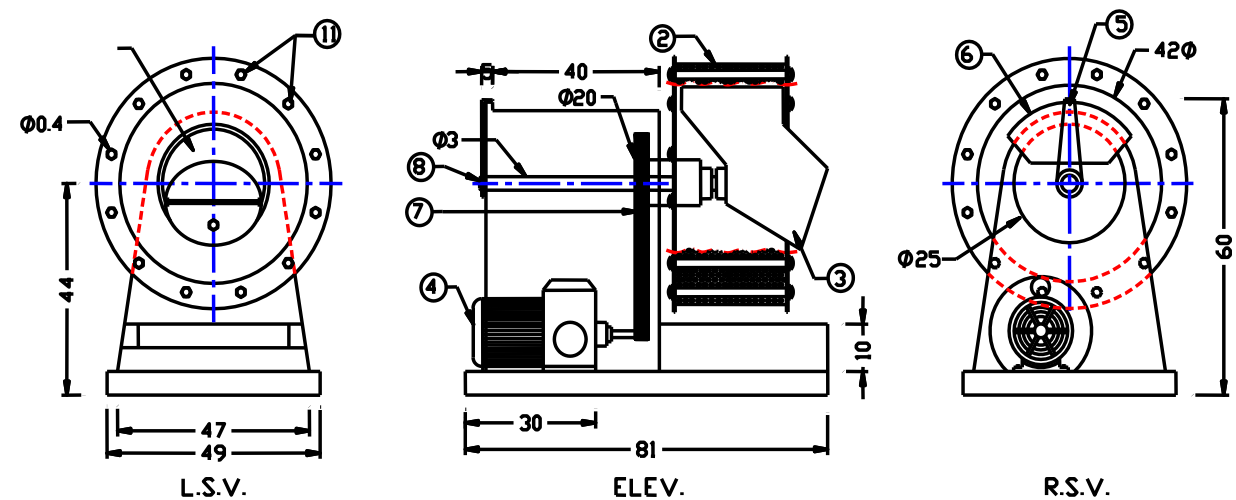

ELEV.

R.S.V.

\begin{tabular}{|c|l|}
\hline $\begin{array}{c}\text { Part } \\
\text { No. }\end{array}$ & \multicolumn{1}{|c|}{ Part name } \\
\hline 1 & Machine base \\
\hline 2 & Indented cylinder \\
\hline 3 & Receiving trough \\
\hline 4 & Electric motor \\
\hline 5 & Trough angle i \\
\hline 6 & \multicolumn{2}{|l|}{ Trough angle scale } \\
\hline 7 & \multicolumn{2}{|l|}{ Chain } \\
\hline 8 & Trough shaft \\
\hline 9 & \multicolumn{2}{|l|}{ Shaft guard } \\
\hline 10 & \multicolumn{2}{|l|}{ Input /output port } \\
\hline 11 & \multicolumn{2}{|c|}{ Bolts } \\
\hline Scale1:1 & Dim. In cm \\
\hline
\end{tabular}

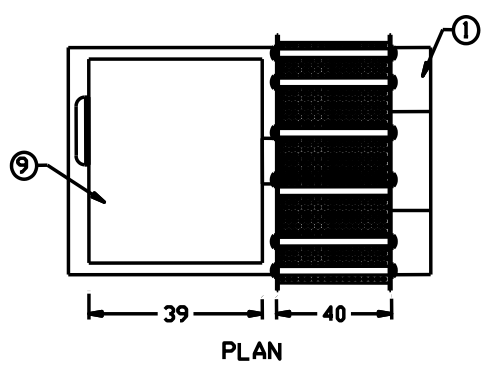

Fig. (1): Elevation, plan and side views of the experimental cylinder separator.

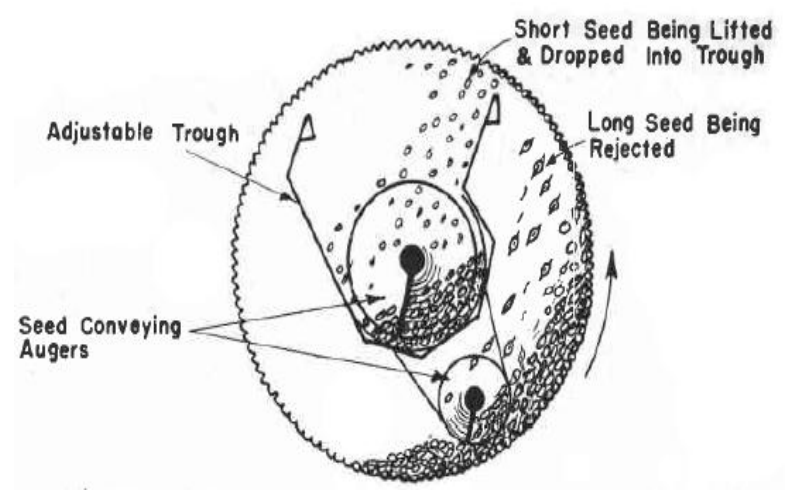

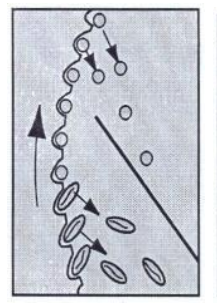

Round-grain separation

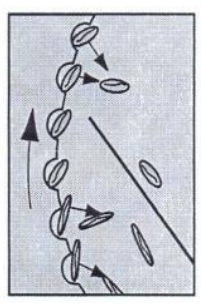

Long-grain separation

Fig.(2):Cross-section view of an indented cylinder separator. 
Table (3): Indicator settings for various cylinder speeds

\begin{tabular}{|c|c|c|}
\hline Cylinder speed (rpm) & Dial reading & Micro crank \\
\hline 30 & 6 & $1 / 2$ turn \\
\hline 32 & 7 & 0 \\
\hline 35 & 7 & $1 / 2$ turn \\
\hline 40 & 8 & 0 \\
\hline 45 & 8 & $1 / 2$ turn \\
\hline 50 & 9 & 0 \\
\hline
\end{tabular}

The experiments were carried out to evaluate a cylinder separator in laboratory to optimize some operating and engineering parameters affecting the separating efficiency at constant separating time of 60 seconds and cylinder slope of $0^{\circ}$ are identified. The parameters are:

1- Four cylinder rotational speeds of 30, 35, 40 and $45 \mathrm{rpm}$. corresponding to peripheral speeds of $0.94,1.10,1.26$ and $1.41 \mathrm{~m} / \mathrm{s}$.

2- Four trough angles of $30^{\circ}, 40^{\circ}, 45^{\circ}$ and $50^{\circ}$.

3 -Four feeding rate levels of $6,12,18$, and $24 \mathrm{~kg} / \mathrm{h}$.

Forces and factors affecting the motion of the lifted grains

As shown in Fig.(3-a), the forces act on the grain moving with the pocket including :the force $(\mathrm{G})$ due to the weight of grain; the normal reaction of the cell $(\mathrm{N})$; the friction force $(\mathrm{F})$ and the inertia force $\left(\mathrm{P}_{j}\right)$. The grain would be in steady state, if the sum of component of all forces along the $\operatorname{axes}\left(X_{1}\right)$ and $\left(Y_{1}\right)$ is equal zero at point $O$ (Klenin et al.,1985), that is:

$P j \sin \beta-G \sin (\omega t-\beta)+F \max =0$

$-P j \cos \beta-G \cos (\omega t-\beta)+N=0$

Where: $\omega=$ angular velocity $\omega t=$ angle of turning of the cylinder

From the above two equations, then:

$$
N=P j \cos \beta+G \cos (\omega t-\beta)
$$

Since $P j=m g . . R \omega^{2}$ and $F \max =f . N \quad$, substituting these in the first expression:

$$
R \omega^{2}(\sin \beta+f \cos \beta)=9.8 .[\sin (\omega t-\beta)-f \cos (\omega t-\beta)] .
$$

Where: $f=$ friction force between the grain and the cell. $\mathrm{R}=$ cylinder radius 
It's known that: $\quad f=\sin \varphi / \cos \varphi$ and $R \omega^{2} / 9.8$ and therefore,

$$
\begin{gathered}
R \omega^{2} / 9.8=k_{T} \\
\text { so, } \quad k_{T}=\sin (\omega t-\beta-\varphi) / \sin (\beta+\varphi)
\end{gathered}
$$

Since $\omega t=90^{\circ}+\alpha$ and for milled and forged cell $\beta \approx \pi / 2$, we have:

$$
\begin{gathered}
\sin (\alpha-\varphi)=k_{T} \cos \varphi \\
\alpha=\arcsin \left(k_{T} \cos \varphi\right)+\varphi \ldots \ldots .
\end{gathered}
$$

Where: $\quad k_{T}=$ kinematic index $\quad \varphi=$ friction angle

So the angle $(\alpha)$,through which the grain is raised in the cell without fall off, depends upon kinematic index $\left(k_{T}\right)$ and friction angle $(\varphi)$.

As shown in Fig. (3-a), for $N=0$ the grains move as projected body at angle $(\pi / 2-\alpha)$ to the horizontal and at $N>0$, the grain started to slip out the cell and fall on the inner surface of cylinder , and angle $\beta=0$, the equation(3) become:
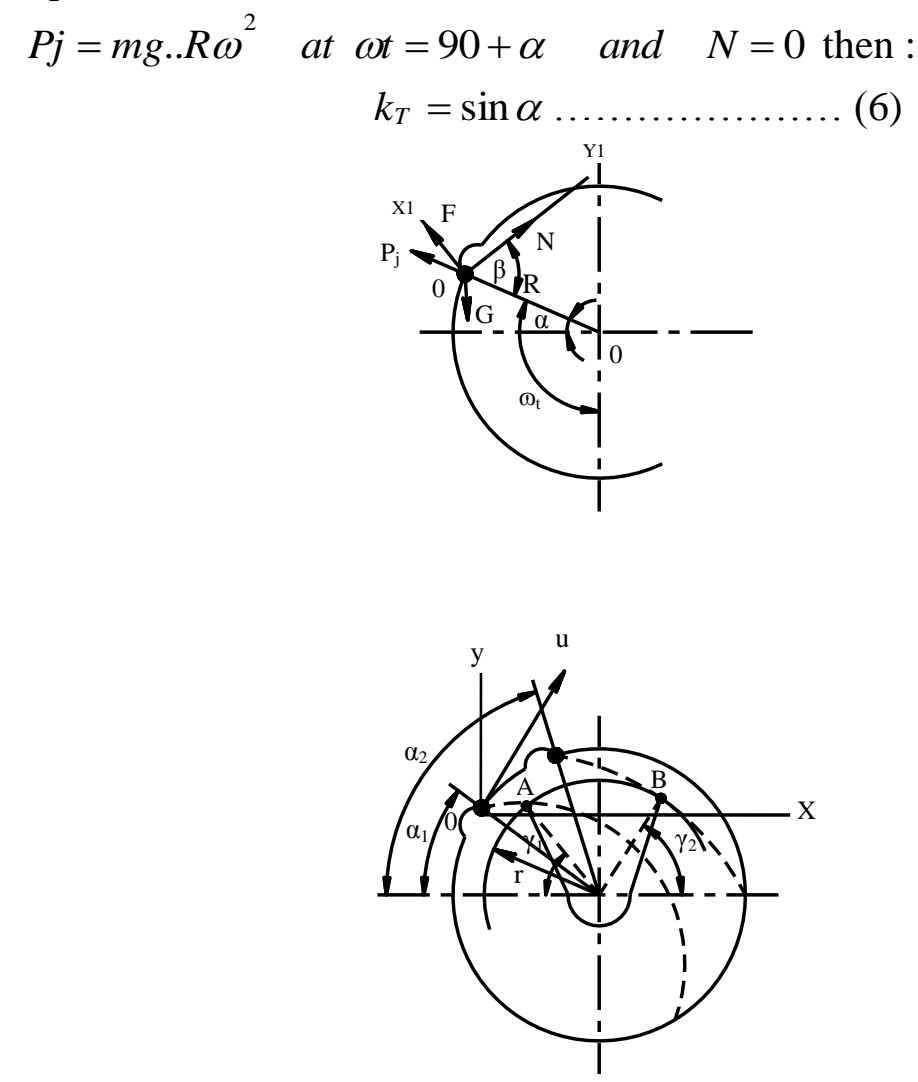

Fig.(3): Diagram of forces affecting the motion of the lifted grains. 
When $k_{T}=1 \quad\left(\alpha=90^{\circ}\right)$, the grain reaches its highest point where the absolute velocity becomes horizontal. In this position , the grain can not slip out of the cell since its free fall trajectory goes beyond the confines of cylinder and hence $\left(k_{T}\right)$ must be less than unity ( $k_{T}$ varies from 0.5 to 0.7).

As shown in Fig(3-b), The position of points $A$ and $B$ may be describe by angles of $\gamma_{1}$ and $\gamma_{2}$.the magnitude of these angles depends up on the friction coefficient $f$ of the grain over the cell surfaces and on the kinematic index $k_{T}$ of the grader. With increase of $f$ and $k_{T}$, angle $\gamma_{1}$ and $\gamma_{2}$ decreases.

\section{Separating efficiency}

Random samples were taken from the two varieties of wheat and corn, then the average percentage of short grains (including the under-size and broken) and the long grains were calculated. For wheat, the percentage were about $20.58 \%$ and $79.42 \%$ for short and long grains respectively, but for corn, the percentages were about $72.54 \%$ and $17.46 \%$ for short and long kernels respectively. In every treatment, the samples of grains were taken from both the cylinder and the receiving trough after separating operation and weighed and then the efficiency was calculated as the percentage of separated short grains in the trough as follows:

Separating efficiency, $\%=\frac{\text { weight of separated short grains in trough }}{\text { Weight of short grains in sample }} \times 100$

Hence, the separated long grains in the receiving trough were calculated as losses as follows:

Lifted long grains (Losses), $\%=\frac{\text { weight of separated long grains in trough }}{\text { Weight of long grains in sample }} \times 100$

The main dimensions of the used grains were measured by an electronic digital varnier caliper with 4 digit display (model METR ISO_G made in Japan), the range of reading is 0.05 to $15 \mathrm{~mm}$ with an accuracy of $1 / 20$ $\mathrm{mm}$. 


\section{RESULTS AND DISCUSSIONS}

\section{1-Effect of cylinder speed on separating efficiency}

Figs.(4 and 6) showed the effect of four cylinder rotational speeds of 30 , 35,40 and $45 \mathrm{rpm}$ corresponding to peripheral speeds of $0.94,1.10,1.26$ and $1.41 \mathrm{~m} / \mathrm{s}$ respectively on separating efficiency for both wheat and corn on the basis of length separating for seeding. The obtained results showed that as the cylinder speed increased from $30 \mathrm{rpm}(0.94 \mathrm{~m} / \mathrm{s})$ to 45 $\mathrm{rpm}(1.41 \mathrm{~m} / \mathrm{s})$, the maximum values of separating efficiency of wheat were decreased by $28.30,38.04,49.55$ and $57.57 \%$ for trough angles of $30^{\circ}, 40^{\circ}, 45^{\circ}$ and $50^{\circ}$ respectively using feeding rate of $6 \mathrm{~kg} / \mathrm{h}$. On the other hand, Figs. (5 and 7) display that by increasing the cylinder speed, the percentage of lifted separated long grains in the receiving trough increased under all values of operating parameters for wheat grains. The same trend was occurred with corn grains. This phenomenon could be attributed to the increase of the angular velocity, consequently the centrifugal force would increase which would confine the grains in the cell, so the grains could not slip off the cell of and exceeds the highest point when the angle $(\alpha)$ equal $90^{\circ}$ (according to Klenin et al.,1985) which lead to lift the short and long grains and throw them away of trough and fall on the inner surface of the cylinder again. From previous data, it is clear that slower rotational speed of $30 \mathrm{rpm}(0.94 \mathrm{~m} / \mathrm{s})$ gave the highest values of separating efficiency of 92.54 and $91.35 \%$ for wheat and corn respectively at feed rate of $6 \mathrm{~kg} / \mathrm{h}$ and trough angle of $30^{\circ}$.

\section{2-Effect of trough angle on separating efficiency}

In this study, four nominal receiving trough angles of $30^{\circ}, 40^{\circ}, 45^{\circ}$ and $50^{\circ}$ were tested. As illustrated in Figs. ( 5 and7), the results cleared that the separating efficiency for both varieties of wheat and corn decreased by increasing the trough angle. For wheat, the increase of angle of front wall of trough from $30^{\circ}$ to $50^{\circ}$ would decreased the highest values of separating efficiency by $35.66,48.09,57.47$ and $61.94 \%$ for cylinder speeds of 30,35,40 and $45 \mathrm{rpm}$ respectively under feeding rate of $6 \mathrm{~kg} / \mathrm{h}$. The same trend was observed with grains of corn, where the highest values of separating efficiency decreased by $30.45,30.60,48.03$ and $54.67 \%$ for cylinder speeds of 30,35,40 and45 rpm respectively under feeding rate of $6 \mathrm{~kg} / \mathrm{h}$. The clear decrease in separating efficiency for corn 

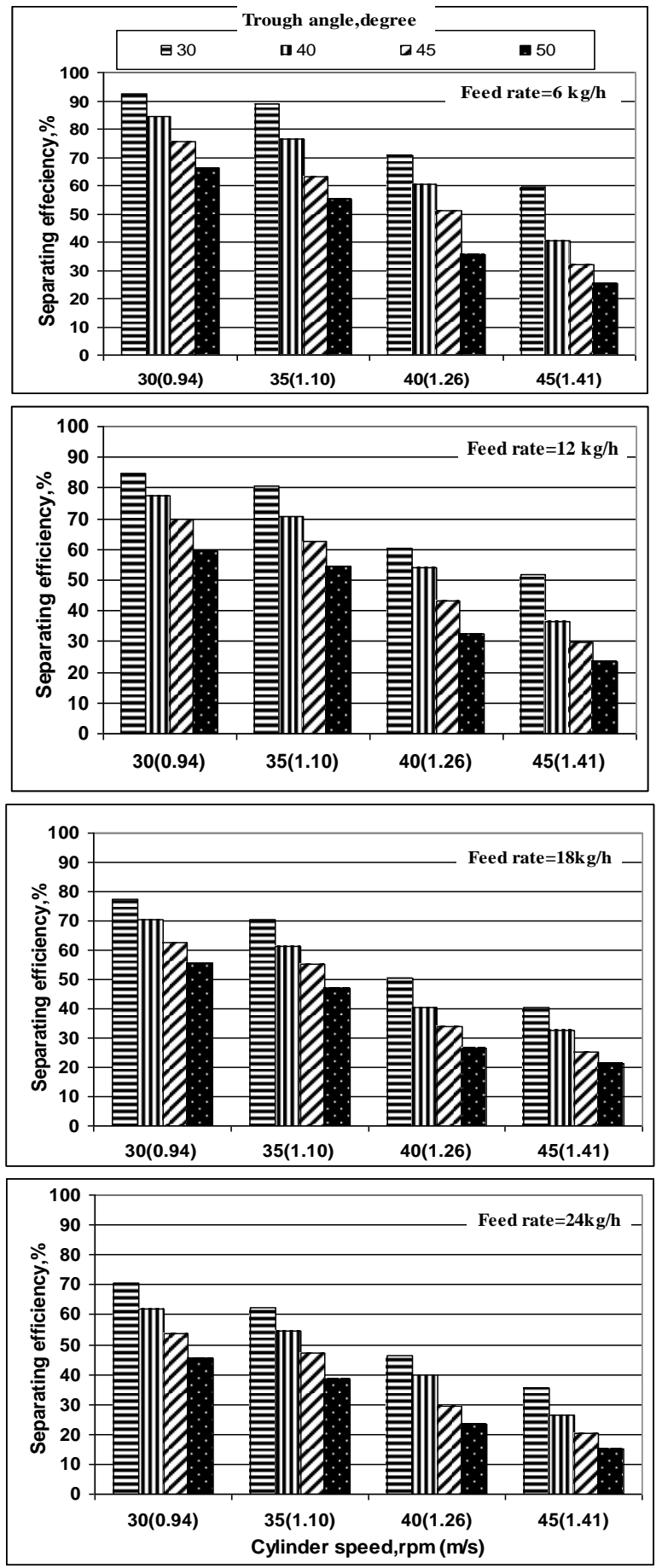

Fig.(4):Effect of cylinder speed on separating efficiency for wheat under different trough angles and feeding rates. 

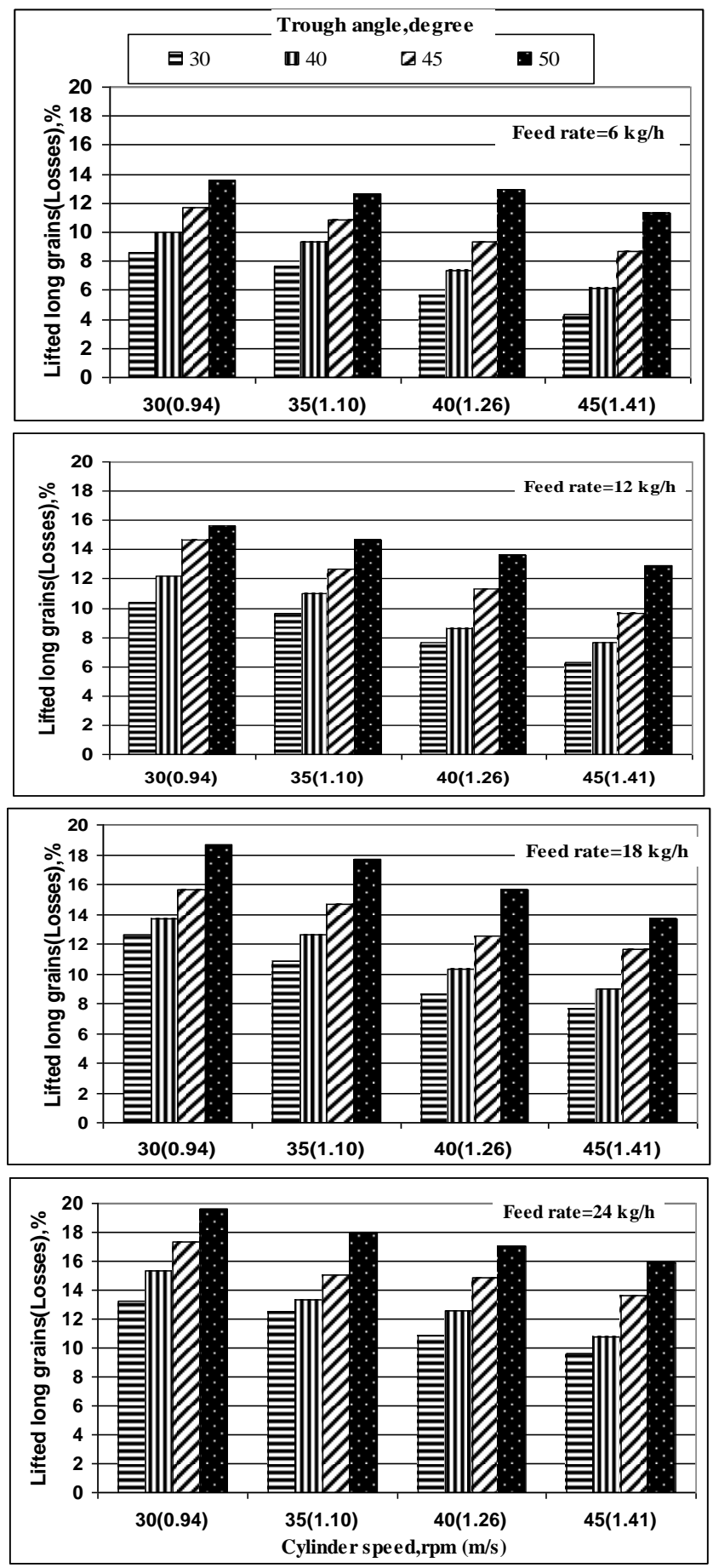

Fig.(5):Effect of cylinder speed on grains losses for wheat under different trough angles and feeding rates. 
than wheat may be expected because that the magnitude of the front wall angle of trough $\left(\gamma_{1}\right)$ and the rear wall $\gamma_{2}$ (as shown in Fig. 4-b) depends on the friction coefficient $(f)$ and the kinematic index $\left(k_{T}\right)$, since the friction coefficient over the cell surface for corn grain higher than wheat, the trough angle $\left(\gamma_{1}\right)$ increased and $\left(\gamma_{2}\right)$ decreased by increasing of $f$ and $k_{T}$. .Hence, it can be used higher angles of trough with corn grain especially with moderate speeds of cylinder (35 to $40 \mathrm{rpm}$ ). On the other side, Figs. ( 6 and 8 ) indicated that the percentage of lifted separated long grains decreases insignificantly as the trough angle increased from $30^{\circ}$ to $50^{\circ}$ at slower speeds ( 30 to $35 \mathrm{rpm}$ ) and a clear decrease at higher speeds (40 to $45 \mathrm{rpm}$ ), for both wheat and corn grains. It is obvious that, the receiving trough angle plays an important role in controlling the separating accuracy which depends upon the angle of wall of the trough with horizontal .Hence, the optimum values of receiving trough angle were $30^{\circ}$ and $40^{\circ}$ which gave the highest values of separating efficiency of $92.54,88.85 \%$ and $91.38,86 \%$ for wheat and corn respectively with minimum percentage of lifted long grains in the trough.

\section{3-Effect of feed rate on separating efficiency}

Four feed rates of $6,12,18$ and $24 \mathrm{~kg} / \mathrm{h}$ were selected to investigate their effect on separating efficiency for both of wheat and corn grains as displayed in Figs. (4 and6). The obtained results revealed that the separation efficiency decreased by increasing the feed rate from 6 to $24 \mathrm{~kg} / \mathrm{h}$ under at the whole values of the operating parameters for grains of wheat and corn. Fig.(4) showed that the recorded data of separation efficiency of wheat were $92.54,84.75,77.54$ and $70.65 \%$ for feed rates of $6,12,18$ and $24 \mathrm{~kg} / \mathrm{h}$ respectively while for corn grains were 91.35 , $32.35,76.40$ and $69.50 \%$ for feed rates of $6,12,18$ and $24 \mathrm{~kg} / \mathrm{h}$ respectively at trough angle of $30^{\circ}$ and cylinder speed of $30 \mathrm{rpm}(0.94$ $\mathrm{m} / \mathrm{s}$ ).This decrease may be due the fact of that the increase of grains feed rate would increase the number of short grains in treatment sample, so when the indented cylinder starts to rotate ,more than one of short grains next to the inner surface of cylinder would drop into every indent and lifting them from the grain mass by the latter and consequently, the grains would be unstable and the indent could not confine the grains and 

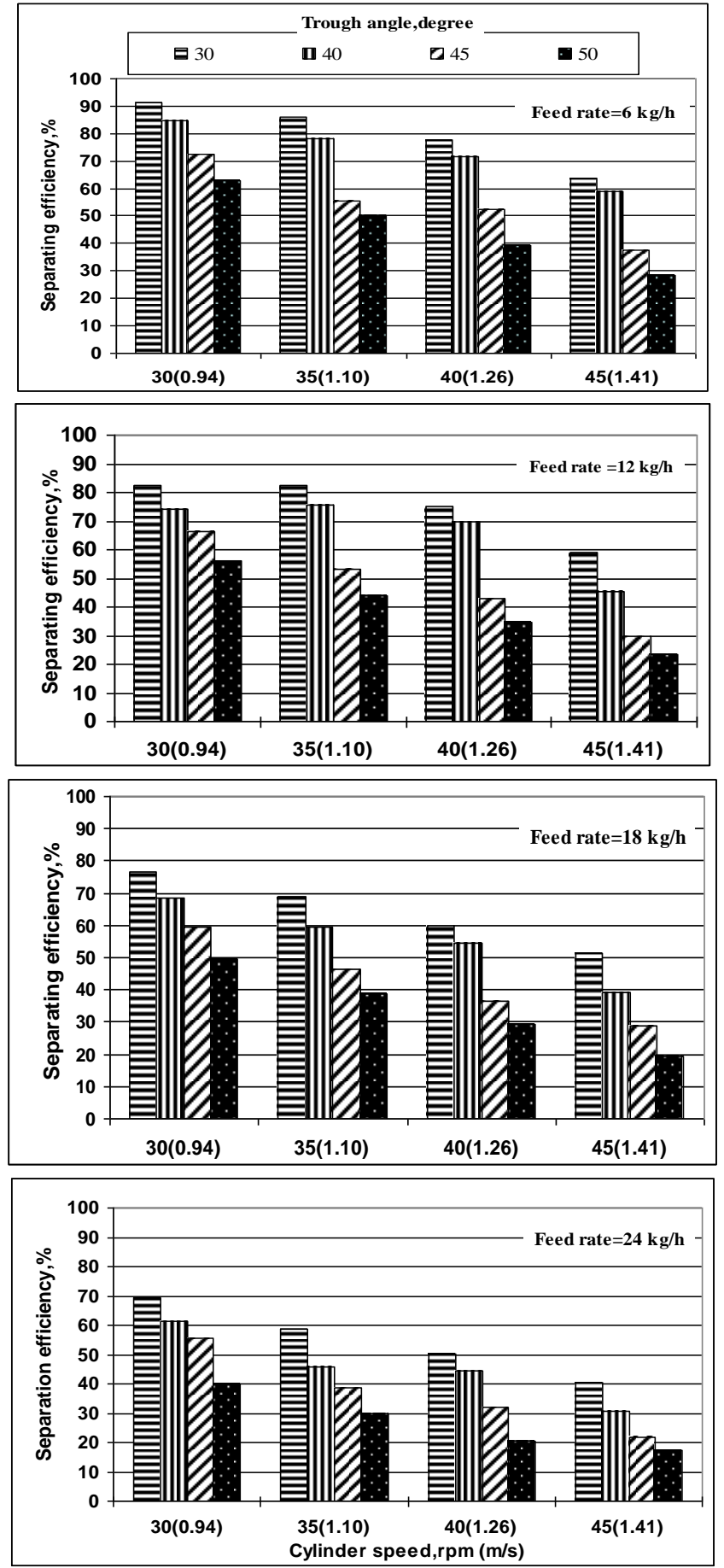

Fig.(6):Effect of cylinder speed on separating efficiency for corn under different trough angles and feeding rates. 

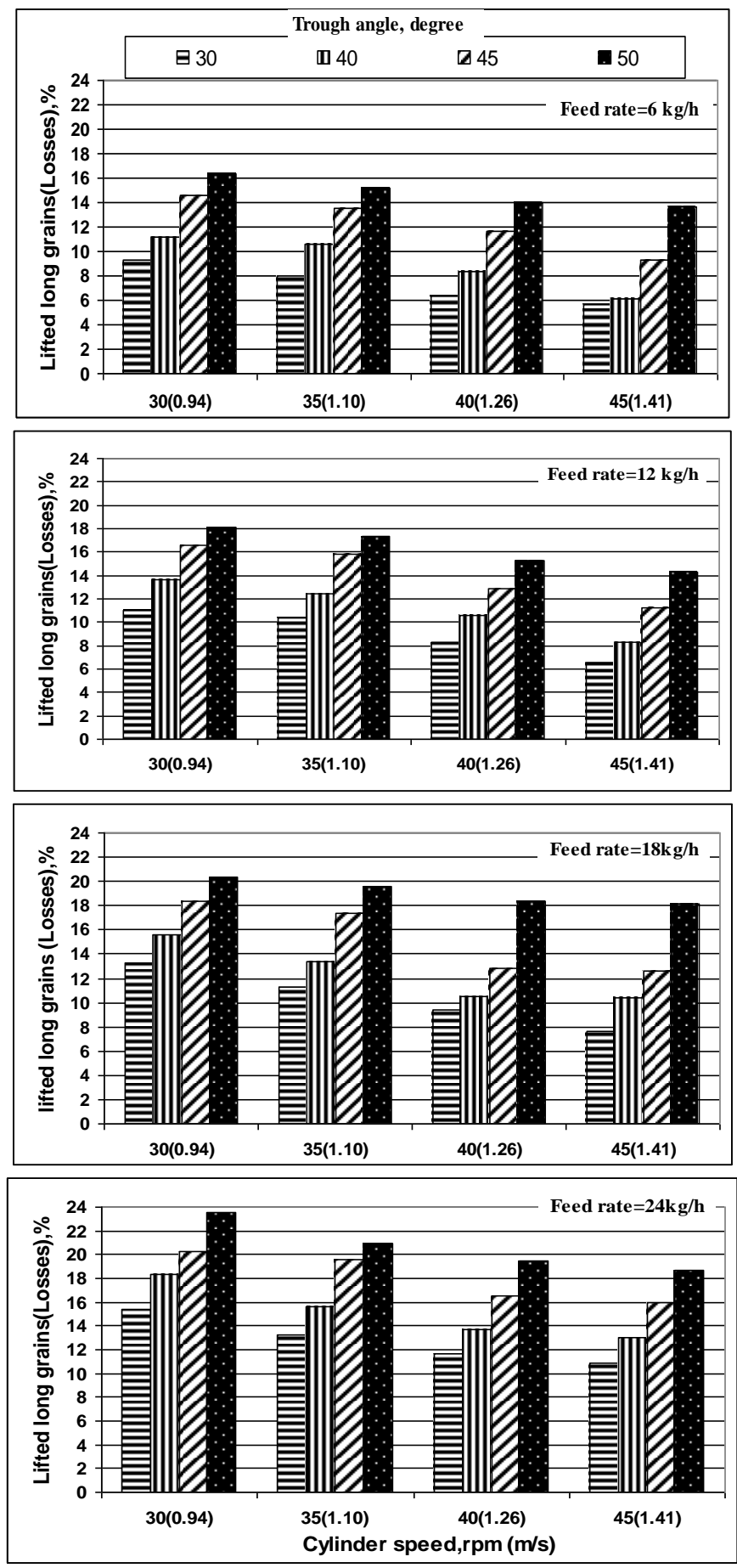

Fig.(7):Effect of cylinder speed on grains losses for corn under different trough angles and feeding rates. 
would reject them to fall down to the long grains in the cylinder at lower height. Figs. (5 and 7) depicts that the lifted long grains increased by increasing the feed rate for wheat and corn. The obtained results showed that increase of feed rate from 6 to $24 \mathrm{~kg} / \mathrm{h}$ would increase the lifted long grains from 8.63 to $13.23 \%$ for wheat and from 9.32 to 15.36 for corn at cylinder speed of $30 \mathrm{rpm}(0.94 \mathrm{~m} / \mathrm{s})$ and trough angle of $30^{\circ}$. This increase may be attributed to the large of number of the lodged long grain which may share the indent with the short grains especially at the high speeds of cylinder under the effect of centrifugal force. It is clear that, the feeding rate is one of the most effective factors on separating accuracy of the machine.

\section{CONCLUSION}

The obtained results indicated that the cylinder separator can be operated at rotational speeds ranged from $30 \mathrm{rpm}(0.94 \mathrm{~m} / \mathrm{s})$ to $35 \mathrm{rpm}(1.10 \mathrm{~m} / \mathrm{s})$ and receiving trough angles from $30^{\circ}$ to $40^{\circ}$ and feed rate of $6 \mathrm{~kg} / \mathrm{h}$ to achieve the best values of separating efficiency with minimum percentage of lifted long grains in the trough for wheat and corn. So the combination of $30 \mathrm{rpm}(0.94 \mathrm{~m} / \mathrm{s})$ cylinder speed, $30^{\circ}$ trough angle, and 6 $\mathrm{kg} / \mathrm{h}$ feed rate is recommended for the best separating efficiency of 92.54 and $91.35 \%$ for wheat and corn respectively.

\section{REFERENCES}

\section{Berlage, A.G., D.M Bilsland, N.R. Brandenburg and T.M Cooper}

1984. Experimental indented cylinder for separating seed. Trans. of the ASAE, 27 (2): 358- 361.

Fouad, H.A. 1980. The effect of cell configuration on length grading of beans. J. Agric. Eng. Res., England, 25:391-404

Klenin, N. I., I. F. Popov and V.A. Sakun 1985.Agricultural machines. Theory of operation, computation of controlling parameters and the condition of operation .Amerind Publishing Co.,PVT.Ltd., New Delhi, India :483-488 PP.

Sarkar, A.K. 1993. Flour milling. In: Grains and oilseeds- Handling ,Marketing and Processing. Vol. 2, $4^{\text {th }}$ ed., Canadian International Grain Institute, Winnipeg, Canada. 
Wang, Y. J., D. S. Chung, S. R. Spillman, S. R. Eckhoff, C. Rhee and H. H. Converse 1994. Evaluation of laboratory grain cleaning and separating equipment - Part 1. Trans. of the ASAE, 37(2): 507513.

Yamashita, R. 1985. Rice processing machinery. Textbook of Japanese International Cooperation Agency (JICA), Kyoto University, Japan.

الملخص العربى

\section{العوامل المؤثرة علي أداء أسطوانة الفصل ذات التجاويف

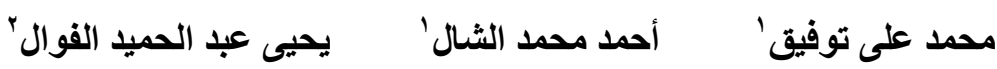

يهدف هذا البحث لدراسـة بعض العوامل الهندسية المؤثرة علي أداء جهاز الفصل الأسطو اني

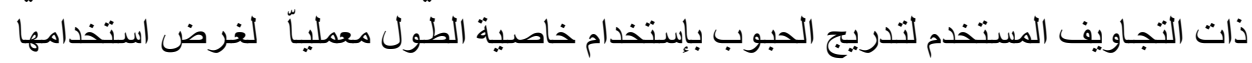

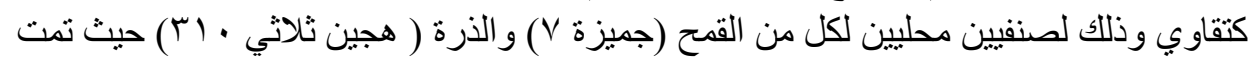

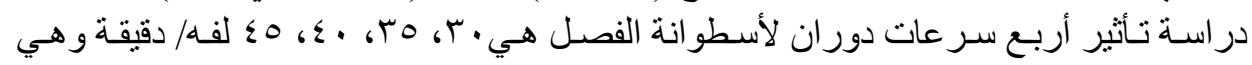

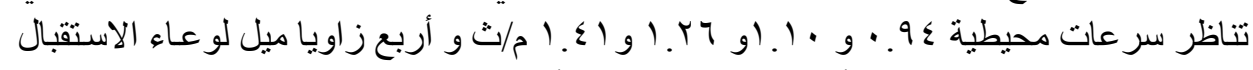

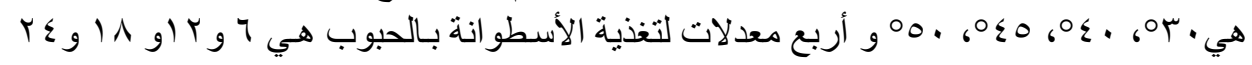

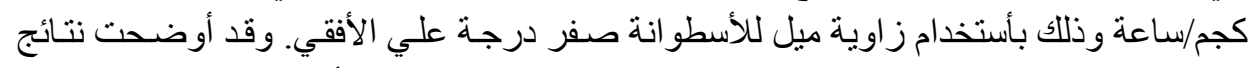

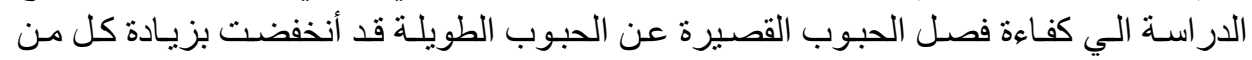

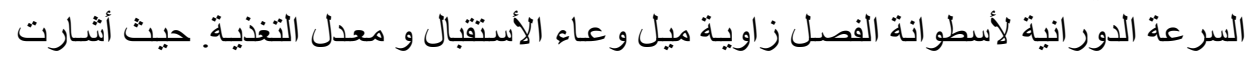

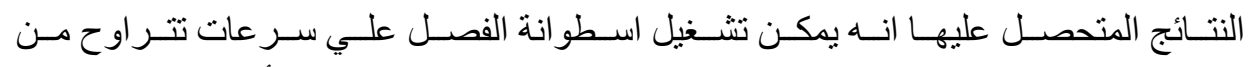

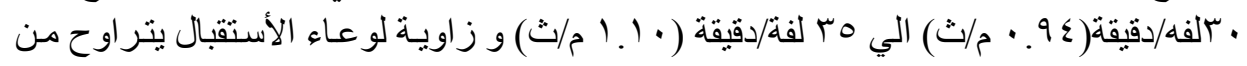

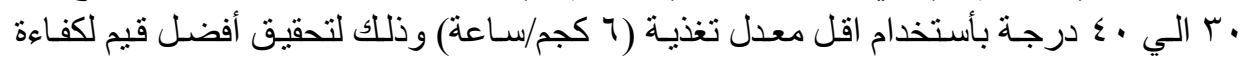

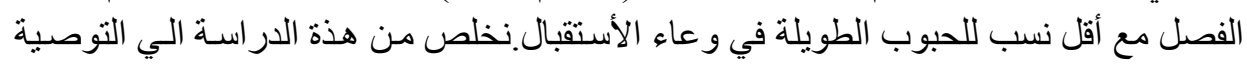

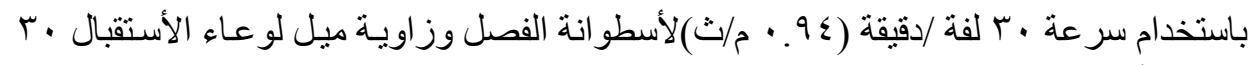

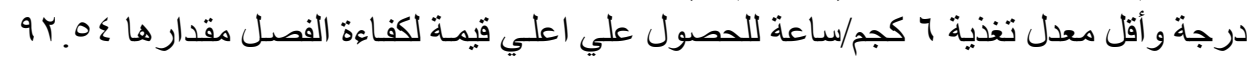
و وه. 19\% لكل من حبوب القمح و الذرة علي التو الي.

$$
\begin{aligned}
& \text { مدرس الهندسة الزر اعية ـ كلية الزر اعة - جامعة الزقازيق - مصر. } \\
& \text { r باحث بمعهد بحوث الهندسة الزر اعية ــ الجيزة ـ مصر. }
\end{aligned}
$$

